\title{
COMMUNICATION AND CUSTOMER RELATIONS STRATEGY IN IMPROVING HOTEL GUESTS' SATISFACTION IN SAMOSIR TOURISM AREA, NORTH SUMATRA, INDONESIA
}

\author{
Yossie Rossanty, M.D.T.P, Nasution, I. Irawan \\ Universitas Pembangunan Pancabudi, \\ Department of Management, Faculty of Social Science, \\ Medan, North Sumatra, Indonesia
}

\begin{abstract}
The present study examines and analyzes the strengths and weaknesses of the communications and customer relationship strategies that have been developed by public relations and individually simultaneously, influencing guests to visit at Hotels in Samosir. The research population is Hotel managers located on Samosir Island with saturated sample techniques where population units are sampled as a whole. Then, the data obtained were analyzed using regression analysis based on the Structural Equation Modeling (SEM) Partial Least Square (PLS). The empirical results of this study have shown that customer relationship marketing has an effect on the satisfaction of hotel guests. The success of the Hotel strategy in the Samosir area has given the guests satisfaction that has been a parameter for their future hotel success. Hotels that have failed in general have suffered a loss of trust and dissatisfaction with guests and communities. The communication strategies that have been established by the customer relationship hotel in Samosir area have shown good strategy. The customer relationship strategy that hotels in Samosir have created to increase guest satisfaction among them; Hotel provides Family Gathering activities. Family gatherings are of two types employee gatherings are a regular event for all employees to develop intimacy between employees. Customers gathering is a special event for guests to foster relationships. Customers relationship Hotel in Samosir area also has strategies in handling guest complaints. The strategy of the Hotel in the Samosir area in dealing with guest complaints is through a cooperative approach to guests. Customers relations Hotel in Samosir area is divided into two parts; guest service and customer information section. The existing customer relations of the Samosir Hotel has become a mediator that connects the agency with its guests. The needs of any guest they want should go through the customer relations section. Here the role of customer relations is also the communicator of the agency. The service department has the task of welcoming guests; providing services for all guests' needs and providing information on procedures. Customer relations have been able to increase hotel guests' satisfaction in Samosir area
\end{abstract}


through innovation. It has been proven to increase the satisfaction of hotel guests. It is also closely linked to the hotel's customer relations strategy.

Keywords: Customer, Relation, Communication, Strategy, Hospitality, Hotel, Satisfaction

Cite this Article: Yossie Rossanty, M.D.T.P, Nasution, I. Irawan, Communication and Customer Relations Strategy in Improving Hotel Guests' Satisfaction in Samosir Tourism Area, North Sumatra, Indonesia, International Journal of Management (IJM), 10 (6), 2019, pp. 88-98.

$\mathrm{http}: / /$ iaeme.com/Home/issue/IJM?Volume $=10 \&$ Issue $=6$

\section{INTRODUCTION}

The industrial revolution 4.0 era will impact businesses in developing the products or services offered. Companies need to change their orientation to the level of customer satisfaction. The rapid growth of the hotel services business primarily in the tourist areas is not due to competition in the hotel business environment alone. It requires the right strategies and aims to find and retain as many customers as possible while expanding the market. The current competitive situation can undoubtedly have a positive and negative impact. Each hotel will compete to provide the best services and facilities for its customers. It is expected to capture consumer satisfaction with the hotel, which has an impact on the hotel's guests. Similar to the hotels in the Samosir tourist area. It is the rapid growth of hotels that has enabled the Hotel Managers to develop effective strategies to compete with them. Satisfaction-oriented hotels tend to focus on meeting their needs and wants. However, accomplishing goals, sometimes the hotels often neglect the rights of the guests who have already given their obligations to the company. In terms of hospitality, it is not uncommon for guests to complain about the poor service of the company. It underlines the importance of the right communication strategies to create excellent satisfaction.

Public relations are a valuable role for businesses. Their role is not only to build a corporate image, but also to provide corporate service to the public. In addition to tasks related to internal and external public, the task of public relations is to emphasize the image of the company which is represented to avoid misunderstanding and to eliminate potential negative issues to the corporation [1]. Customer relations activities will impact the image of the Hotel, which is shaped by positive or negative customer opinions. Positive opinions occur when companies and customers have a harmonious relationship. These activities are assigned to the Public Relations division. If customer relations activities are ongoing, then the hotel's guests' satisfaction will remain awake and may continue to improve.

There are several Public Relations Hotel activities in the tourism area of Samosir, which have been promoting national and international coverage. Promotions of national events such as TOBA festival, with a variety of local art events, are BATAK and have been held regularly every year. International Promotions in the ASEAN Tourism Forum (ATF) and the Malaysia Association of Tour and Travel Agent (Matta Travel Fair). Customer relations Hotel has varied and varied activities such as the SBC Weekend Package, which is an SBC package combined with the tour of Samosir buses or special events, other events are regular program innovations. Public Relations Hotel also provides services by inviting hotel guests to the airport for free. It is a way for hotels to increase their customer satisfaction. Improving the quality of human resources and enhancing facilities and services are a top priority in gaining visitors. Welcome drink is also a way that Public Relations Hotel is engaged in customer relations activities. The problematic factor identified for hotels in the Samosir area is that the rate of hotel guests' attendance declines on a normal day that affects the business activities of several hotels in 
Samosir. These conditions and conditions are due to the fact that some guests have complained about the services being offered such as orders that are not in line with guests' expectations, delays in service delivery, and facilities are less than the price provided. In addition, the sinking incident in Samosir indicates that the active role of the community has not fully reflected safety, which may cause tourists to refuse to visit Samosir. Here the role of Public Relations Hotel is to convince and communicate with customers. Public relations through communication and customer relations strategies is an attempt to increase guests' satisfaction, which is likely to increase visitors' attendance is interesting to study.

\section{LITERATURE REVIEW}

\subsection{Communication}

Communication is an activity that communicates what we have in mind, the concepts we have and the desire we want to convey to others. As an art to influence others to get what we want [2]. Communication is a transaction, a symbolic process that requires people to control their environment by 1) building interpersonal relationships; 2) through the exchange of information; 3) strengthens attitude and behavior to others; 4) attempts to change that attitude and behavior [3]. Communication is the process of transferring or exchanging information. Verbal or nonverbal information [4]. Communication is a process of communicating messages by the communicator to the communicant through media that has specific effects [5].

Communication has several characteristics, as follows: a)Communication is a process. Communication as a process which means communication is a series of actions or events that occur sequentially (there are stages or frequencies) and are related to each other within a specified period. b) Communication is a deliberate and purposeful endeavor. Communication is an act that is consciously, intentionally, following the purpose or desire of the actors. c) Communication requires the participation and cooperation of the actors involved in communication activities that will take place are useful if the parties who communicate (two or more) are equally involved and share the same attention to the topic of the message delivered. d) Communication is symbolic. Communication is basically an action that uses symbols. The most commonly used symbol in communication between humans is verbal language such as words, sentences, numbers, or other signs. e) Communication is transactional. Communicate by agreeing to accept two actions, namely giving and receiving. These two actions are balanced or proportionally necessary. f) Communication penetrates space and time factors. Participants or actors involved in communication are not even present at the same time and place. Because, through various communication technology products such as telephone, internet, space, and time factors did not have become a problem in communication.

\subsection{Forms of Communication}

Communication consists of four forms; self-communication, inter-personal communication, public communication and mass communication [3].

Self-Communication. The process of communication occurs within the individual, or in other words, the communication process itself. The process of communication is due to the fact that someone is giving meaning to an object that he or she has in mind. Objects such as natural events, events, experiences, facts that are meaningful to humans, whether they occur outside or within themselves

Interpersonal Communication. The process of communication takes place between two or more persons face to face. According to the nature of communication, interpersonal communication is distinguished between two types; Dyadic Communication and Small Group Communication. Dyadic Communication is a process of communication that takes place between two persons in a face-to-face situation. 
Public Communication. Common public communication is called speech communication, collective communication, rhetorical communication, public speaking, and audience communication. In any case, public communication represents the process of communication which the speaker delivers messages in a face-to-face situation in front of a broader audience. Public communication has the characteristics of interpersonal communication. The reason is that they are face-to-face, but some fundamental differences make them unique. Messages conveyed in public communication are continuous.

Mass Communication. The process of communication takes place where messages are sent from sources such as institutions to a mass audience. Mass communication has the nature of an open message with a diverse audience in terms of business, religion, tribe, occupation, and need.

\subsection{Communication Process}

The process of communication involves the following elements [5]: 1) Sender: a communicator that conveys a message to a person or a number of people. 2) Encoding: the process of encoding, which is the process of transforming the mind into a slender form. 3) Message: a message that is a set of meaningful symbols conveyed by communicators 4) Channel: a communication channel where the messages flow from communicator to communicant. 5) Decoding: the process by which communicants assign meaning to the symbol conveyed by communicators to them. 6) Receiver: communicator receiving messages from the communicator 7) Response: A set of reactions to communicants after the message has been sent. 8) Feedback: communicative response when conveyed to the communicator. 9) Noise: unintentional interruption in the communication process as a result of receiving other messages by the communicants that differ from the messages conveyed by communicators to him or her. The communicator needs to know which audience is the target and what response they want. He or she must be skilled at encoding messages by considering how the target communication usually controls the message password. The communicator should send the message through efficient media to reach the target audience. The essence of communication is a process of human expression that expresses one's thoughts and feelings toward others by using language as their medium of communication.

\subsection{Elements of Communication}

The study by [3] noted that the elements of communication, among others: Source. All communication events will involve the source as the sender of information. The source of interhuman communication consists of an individual, but may also form groups such as parties, organizations or institutions. Sources are often called communicators or source, sender or encode. Message. A message in the communication process is something that the sender sends to the recipient. Messages are delivered face-to-face or through communication media. Content or information such as science, entertainment, information, advice, or propaganda. Media, is a tool used to transmit messages from sources to the receiver. Media forms such as interpersonal communication, the senses are considered communication medium. Media in mass communication is a tool that connects open-source and receiver. In other words, everyone can see, read, and hear it. Receiver. The receiver is the target person for the message sent by the source. Receivers can be one or more people, and they can be in groups, parties or countries. Receivers are commonly referred to in a variety of terms, such as audience, goals and the communicants. Effects. The effect is the difference between what a recipient thinks, feels, and does before and after receiving a message. The effect can be on the knowledge, attitude, and behavior of the individual. The effect is also defined as a change or reinforcement of one's beliefs, attitudes, and actions as a result of receiving a message. Feedback. A form of effect originating from the recipient. However, feedback may also come from other elements such as messages and media, even if the message is not yet available to the recipient. Environment. Also called situations are certain factors that may affect the way communicate. The factors are 
classified into four types; physical environment, socio-cultural, psychological, and time dimension.

\subsection{Communication Strategies}

Basically, the strategy is the different stages of the optimal response to the new challenges that the company may face, either as a result of the previous step or due to external pressures. Communication strategy is the ability to choose the use of communication to build common ground among people within the organization. According to [6], the communication strategy needs to focus on the following to achieve the success of the company. a) Customer Relationship. Establishing a business relationship with the customers within a specified period. b) Customer Retention. Rretaining existing customers, this would be a lot cheaper than finding new customers. c) Customer Referrals. If the customers are satisfied, they will revisit and even invite their family or friends. d) Customer Recovery. That is how the company corrects mistakes and turns them into opportunities.

A scholar such as [7] explains that communication strategies need to take the following actions: 1) Encourage mutual trust. Communication begins with an atmosphere of mutual trust created between communicators and communicants. Without mutual trust will hinder communication. 2) Increase feedback. Misunderstandings can be reduced if the feedback process has been done correctly. A communicator needs a feedback mechanism to find out if the communicant has already gotten the message delivered. 3) Manage information flow. The goal is to manage the flow of information to the communicants. Only essential and necessary information is provided. Communication is organized by quality, quantity, and manner of delivery. The information presented should be systematic, concise, detailed. 4) Repetition. The purpose is to help the communicator interpret a message that is unclear or difficult to understand at the first hearing. For a manager, important issues that are not addressed to the staff can be repeated at least two or three times. 5) Use simple language. Complex languages, technical terms make communication difficult to understand. Almost every idea is presented in simple language to make it easy to understand. 6) Timing. Problems in communication arise when a communicator starts delivering a message when the recipient is not ready to hear it. Therefore, the right way is to manage the time to communicate.

\subsection{Customer Relation}

Customer relation is a person or group of people using one or more of the products or services provided [1]. Customer Relation is a customer-related job, and companies must improve communication with their customers and express their concern to customers. Meanwhile, Customer Relationship Management is a strategy in a business process that aims to develop and maintain the customers' relationship. A study by [8] notes that CRM is a company's attempt to concentrate on retaining customers by collecting all forms of customer interaction through telephone, email, and discussion with sales and marketing staff [8].

\subsection{Satisfaction}

Satisfaction is a condition that reflects fulfillment and even exceeds customer expectations for a product or service [9]. Customer satisfaction is the feeling of happiness or frustration after comparing product performance to their expectations [10]. Customer satisfaction is an afterservice evaluation, where the performance of an alternative of a selected product or service meets or exceeds customer expectations. Meanwhile, dissatisfaction arises when results do not meet customer expectations [11]. Therefore, the level of satisfaction is a function of the difference between customers receive and expectations. If the performance of the product or service is below the customer's expectations, it will result in dissatisfaction. Generally, satisfied 
customers tend to be loyal, less price-sensitive, and have a positive image of the company. Therefore, the company should aim to meet customer needs and wants in order to achieve customer satisfaction.

The indicators for measuring customer satisfaction, according to [12] are as follows; 1) Tangibles, including physical facilities, equipment, employees, and communication devices. 2) Reliability, the ability to provide promised services immediately, accurately, and satisfactorily. 3) Responsiveness, the desire of staff and employees to help customers and provide service responsibly. 4) Assurance, including knowledge, competence, politeness, and the trustworthiness of employees, free from physical danger, risk, or doubt. 5) Empathy includes the ease of establishing relationships, effective communication, personal attention, and understanding customer needs.

\section{RESEARCH METHODS}

\subsection{Research Data}

Data acquisition via questionnaire to General Managers Hotel in Samosir area with Likert scale measurement. The pilot study on the questionnaire for the validity and reliability analysis of 30 respondents was outside the specified sample. As for the operationalization of variables and measurements are as follows:

Table 1: Operational Variables

\begin{tabular}{|l|l|l|}
\hline \multicolumn{1}{|c|}{ Variable } & \multicolumn{1}{|c|}{ Operational definition } & \multicolumn{1}{c|}{ Indicators } \\
\hline $\begin{array}{l}\text { Strong } \\
\text { Communic } \\
\text { ation } \\
\text { Strategy }\end{array}$ & $\begin{array}{l}\text { the customer can perceive factors } \\
\text { that strengthen the strategies that } \\
\text { have been created and build a good } \\
\text { and profitable relationship [3] }\end{array}$ & $\begin{array}{l}\text { Programs and Deals Offered } \\
\text { Media Promotion } \\
\text { Communication Media } \\
\text { Collaboration with Companies } \\
\text { and Governments } \\
\text { Location }\end{array}$ \\
\hline $\begin{array}{l}\text { The } \\
\text { weakness } \\
\text { of the } \\
\begin{array}{l}\text { Communic } \\
\text { ation } \\
\text { Strategy }\end{array}\end{array}$ & $\begin{array}{l}\text { factors influencing the operation of } \\
\text { customer relations strategies } \\
\text { whether internal or external factors } \\
\text { are weakening the strategy [3] }\end{array}$ & $\begin{array}{l}\text { Hotel competition } \\
\text { Competitive prices } \\
\text { Inadequate facilities } \\
\text { Service is unsatisfactory }\end{array}$ \\
\hline $\begin{array}{l}\text { Customer } \\
\text { Satisfaction }\end{array}$ & $\begin{array}{l}\text { Customer satisfaction is a person's } \\
\text { sense of happiness or frustration } \\
\text { that arises after comparing a } \\
\text { product's perceived performance to } \\
\text { their expectations [10] }\end{array}$ & $\begin{array}{l}\text { Tangibles } \\
\text { Reliability } \\
\text { Responsiveness } \\
\text { Assurance } \\
\text { Empathy }\end{array}$ \\
\hline
\end{tabular}

\subsection{Research Methods}

Analysis Techniques. Data analysis using the Partial Least Square (PLS) approach. According to [13], Partial Least Square is an alternative approach that shifts from covariance-based SEM to variant-based approaches. Covariance-based SEMs generally test for causality, whereas PLS is more predictive of a model.

Structural or Inner Models, the Inner model represents the relationship between latent variables based on substantive theory. Structural models were evaluated using R-square for dependent constructs, Stone-GeisserQ-square test for predictive relevance and t-test, and significance of structural path parameter coefficients. In assessing the model with PLS, it starts with an R-square interpretation of each latent dependent variable. The interpretation is the same 
as the interpretation of the regression. R-square values can be used to evaluate the effect of certain independent latent variables on whether the latent variable has a substantive effect [13].

Outer Model or Measurement Model, convergent validity of the measurement model with the reflective indicator model was assessed based on the correlation between item score or component score with the construct score calculated by PLS. Reflective measurements are considered high if they are more significant than 0.70 with the measured constructs. Nevertheless, for the early studies of the development of the scale measurement, the loading value of 0.5 to 0.60 is considered sufficient Chin (1998) in [13].

Hypothesis Test, [13] points out the significance of hypothesis testing results with t-test and F-test. Statistical t-test, to test the partial effect of the independent variable on the nonindependent variable assuming that the other variables were considered constant, with a $95 \%$ confidence level $(\alpha=0,05)$.

Determination coefficients Test $\left(\mathbf{R}^{2}\right)$, Determination coefficients are used to determine how well the model is capable of describing dependent variables. If the determinant coefficient (R2) is higher or closer to 1 , then it can be stated that the ability of the independent variable is higher to the dependent variable. On the contrary, if the determinant coefficient (R2) is lower or closer to 1 , then it can be stated that the ability of the independent variable (X) is lower to the dependent variable $(\mathrm{Y})$.

\section{RESULTS \& DISCUSSION}

Evaluate Outer Model or Measurement Models. There are three criteria in using data analysis techniques with SmartPLS to evaluate external models, namely Convergent Validity, Discriminant Validity, and Composite Reliability. Convergent validity of the reflex indicator measurement model was assessed based on the correlation between the component score estimated with Software PLS. The individual reflexive size is said to be high if it is greater than 0.70 with the measured construct. However, according to Chin, 1998 for early-stage studies of the development of scale loading of 0.5 to 0.6 is considered sufficient. In this study, the loading factor of 0.60 was used.

Table 2: Outer Loadings (Measurement Model)

\begin{tabular}{|l|c|c|}
\hline Variable & Indicators & AVE \\
\hline \multirow{4}{*}{ Weakness Communication Strategy } & WCS1 & 0.915 \\
\cline { 2 - 3 } & WCS2 & 0.944 \\
\cline { 2 - 3 } & WCS3 & 0.907 \\
\cline { 2 - 3 } & WCS4 & 0.916 \\
\hline \multirow{4}{*}{ Strong Communication Strategy } & SCS1 & 0.951 \\
\cline { 2 - 3 } & SCS2 & 0.990 \\
\cline { 2 - 3 } & SCS3 & 0.961 \\
\cline { 2 - 3 } & SCS4 & 0.983 \\
\cline { 2 - 3 } & SCS5 & 0.959 \\
\hline \multirow{4}{*}{ Customer Satisfaction } & SF1 & 0.863 \\
\cline { 2 - 3 } & SF2 & 0.959 \\
\cline { 2 - 3 } & SF3 & 0.975 \\
\cline { 2 - 3 } & SF4 & 0.966 \\
\cline { 2 - 3 } & SF5 & 0.922 \\
\hline
\end{tabular}

Table 2 shows that outer model values meet convergent validity, where the loading factor is above 0.60 .

Evaluating Reliability and Average Variance Extracted (AVE). The validity and reliability criteria are derived from the reliability values of a construct and the Average Variance 
Extracted (AVE) values of each construct. The construct has high reliability if the value is 0.70 , and the AVE is above 0.50.

Table 3: Composite Reliability \& Average Variance Extracted

\begin{tabular}{|l|c|}
\hline \multicolumn{1}{|c|}{ Indicator } & AVE \\
\hline Weakness Communication Strategy & 0.848 \\
\hline Strong Communication Strategy & 0.939 \\
\hline Customer Satisfaction & 0.879 \\
\hline
\end{tabular}

Table 3 shows that all constructs meet the criteria of reliability. The composite reliability value is above 0.70 , and the AVE is above 0.50 as the recommended criteria.

Inner Model Test or Structural Models The inner-model test or structural model was evaluated using R-square for t-test dependent constructs and the significance of the structural path parameter coefficients.

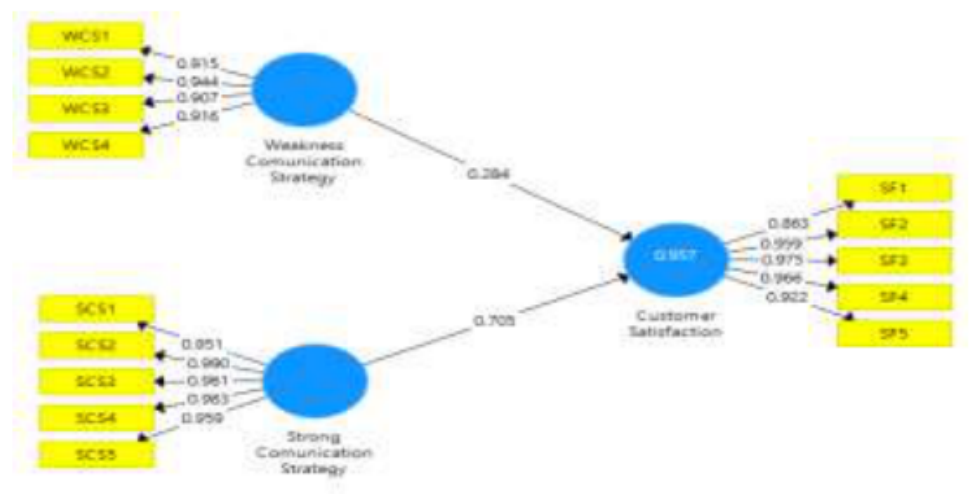

Figure 1. Structural Models

The figure above shows an R-square value of 0.957 or $95.7 \%$. The results indicate that $95.7 \%$ of the hotel guest satisfaction variables are influenced by the variables of communication strategy weakness and communication strategy strength.

\subsection{Hypothesis Test}

\subsubsection{Weakness Communication Strategy is directly and positively related to Hotel guests' satisfaction}

The first hypothesis test results showed that the Weakness Communication Strategy's variable relationship with guest satisfaction showed a path coefficient value of 0.284 with a t-value of 3,273 . The value is higher than the table $(1,960)$. This result means that the Weakness of Communication Strategy has a positive and significant relationship to guest satisfaction. Therefore, the first hypothesis is accepted.

\subsubsection{Strong Communication Strategy is directly and positively related to Hotel guests' satisfaction}

The results of the second hypothesis test showed that the Strong Communication Strategy's variable relationship with guest satisfaction showed a path coefficient value of 0.705 with a $t$ value of 5,532. The value is higher than the table $(1,960)$. This result means that the Strong Communication Strategy has a positive and significant relationship to guest satisfaction. Therefore, the second hypothesis is accepted. 


\subsection{Discussion}

\subsubsection{Customer Relationship Strategy to Increase Customer Satisfaction of Hotels in Samosir Area}

Hotels in Samosir area have several customer relations strategies to build customer satisfaction. 1) Family Gathering is a program created to gather with the entire staff or customer. 2) Promotion Program. Collaborate with the media to deliver messages to potential Hotel guests. 3) Setting Price Policies. The point here is to offer a special price for the company which is different from the general price. Also, adjust prices with other hotels. 4) Become a Sponsor, such as the Football Exercises in 2014. It is an attempt to attract guests to visit Hotels in Samosir. 5) Sales promotion, providing customers with the latest promotional packages, the latest developments in the Hotel, and inviting potential customers to stay in the Samosir area. Television media and Be Magazine. 6) Provide souvenirs such as keychains, welcome drinks, pens, stickers, vouchers, fruit bouquet, or small mugs to guests and customers who regularly use the Hotel function in the Samosir area. The gift of souvenirs is certainly a form of attentiveness and a token of gratitude to the Hotel for its loyal customers using the products and services of the Hotel in Samosir area. 7) Add the room and lounge facilities, and room facilities are synchronized to the customer's needs, such as superior rooms, deluxe, junior suites, indoor or outdoor hotels. 8) Provides a variety of primary and specific menus that are regional characters.

As for the weaknesses in increasing customer satisfaction, among other hotel competition, one of the weaknesses in the presence of new and modern quality hotels. Customers were trying to enjoy the hotel facilities they have never visited. As more and more new hotels grow, guests want to try the new hotel's service and facilities. This case is one of the reasons that hotel competition is a weakness for old hotels, especially Hotels in Samosir area. As such, valueadded services and innovations will make a difference and attract guests. Competing prices, other weakness factors were related to price competition. Therefore, Hotels in the Samosir area must carefully estimate the cost of facilities and services to its customers. Inadequate facilities. Another disadvantage is the lack of facilities that customers enjoy while using the Hotel service in Samosir area. It is necessary to add facilities such as Pubs, Spa and Fitness centers, ATMs, pastries, lounges, room additions, and more to serve the needs of customers. Poor service, a lot of different guests' wants and behaviors are the reason guests are dissatisfied. Employees even study the customer's individual characteristics to find out what they need to do when dealing with different customers daily.

Implementing customer relations strategy is one of the activities of Hotel marketing in Samosir area to stay in touch with customers. Factors that strengthen customer relations strategies that may benefit the Hotel in Samosir area include; Programs and Deals Offered. In implementing the hotel's customer relations strategy, special programs and deals are offered at a special price to the customer. It is to encourage customers to continue to use the products and services of Hotels in the Samosir area. Attractive promotions are offered at affordable prices, and facilities are an excellent choice for some companies and governments to hold workshops or events for their employees. One of the strengths of customer relations strategies to increase customer satisfaction is the ease of spreading promotions through the media. The media is the fastest and most powerful means of conveying messages to reach the public. The communication medium also makes a connection with customer continuous. Collaboration with agencies is a form of good customer relationship that is always on the lookout. It also benefits the hotel in terms of revenue and hotel image in the community. This case is a supporting factor in increasing customer satisfaction. Collaboration with companies and governments can benefit one another and develop connections. Strategic hotel locations are key to the success of Hotels 
in Samosir area in attracting customers and potential guests. The Customer Relations Hotel strategy in Samosir region is functioning well. Hotels in the Samosir area have always built a good relationship between the company and guests, through communication, attitude, and behavior. The company is trying to resolve the guest complaint cooperatively.

The cooperative approach is implemented by providing a specific piece of information whose job it is to handle Hotel guests' complaints in the Samosir area. A program run by the Hotel customer relations in Samosir area is to provide the ultimate service to guests. Customer relations play an essential role in establishing a good relationship between the company and the guest. As much as possible, customer relations are required to maintain good relations with their guests, as they are corporate assets. A customer relationship is also required to be a mediator, creator, conceptualist, and communicator. That is why customer relations should be able to optimize and empower what is happening and growing in the community. Customer relations at the Hotel in the Samosir area are the mediators that connect the agency with the guests. Customer relations is also a communicator of the agency. Guests are a key asset of the company that must maintain a relationship with them for the company's continued success. Others support the successful role of customer relations in supporting corporate management functions to achieve shared goals in the field of guest handling. As stated above, customer relations have a unique role as mediator, where a mediator can communicate directly with his or her guests. The strategy of customer relations in dealing with Hotel guests in Samosir area is good because in the agency there has been a special section dealing with guest complaints. Customer relations in the customs information section can serve as a liaison between guests and agencies.

\section{CONCLUSION}

Hotels in Samosir area have several customer relations strategies to build customer satisfaction. (1) Family Gathering is a program created to gather with the entire staff or customer. In this family gathering event, there are special Employee Gathering and Customer Gathering. (2) Promotion program. Collaborate with various media to deliver messages to potential Hotel guests. (3) Set pricing policies. The point here is to offer a special price, where the price policy or room rate is determined to be able to compete. Hotels in the Samosir area set special prices for corporations that are different from those in general. Also, adjust prices with other hotels. Become a sponsor, such as the 2014 soccer sporting event. Sales promotion, sending customers the latest promotions and product packages, the latest developments on the Hotel, and inviting potential customers to stay in the Samosir area. Create an ad. Hotels in the Samosir area also advertise various media, such as television and Be Magazine. Provide regular souvenirs or souvenirs, such as keyboards, pens, stickers, vouchers, to stay-at-home customers and customers who use the Hotel function in the Samosir area regularly. The gift of souvenirs is undoubtedly a form of attentiveness and a token of gratitude to the Hotel for its loyal customers using the products and services of the Hotel in Samosir area. Increase to facilities; the facilities are synchronized to the customer's needs, such as superior rooms, deluxe, Junior suites, indoor or outdoor hotels. Provides a variety of primary and specific menus that are regional characters.

The customer relations Hotel in the Samosir area explores several ways to create high guest satisfaction. Hotel customer relations in Samosir area can always understand the needs of hotel guests. The need for hotel guests is to receive excellent service and information on the hotel facilities they wish to use. Satisfying needs will directly create the satisfaction of hotel guests. The professionalism shown by the Customer relations Hotel in Samosir area is well on its way. This strategy is done through the way Customer relations always responds to hotel guest complaints or informs hotel services properly to create high guest satisfaction. Hotel relations in the Samosir area are entirely accurate and reliable in providing information so hotel guests 
can understand the information that has been provided. This information directly creates excellent satisfaction for the guest. The speed of the Customer relations Hotel in Samosir area in the hospitality has been excellent.

Be willing to listen to all the hotel guests' complaints carefully while providing the hotel guests with solutions or information that creates high satisfaction. Customer relations Hotel in Samosir is excellent in dealing with hotel guests complaints. The strategy is to interact directly with the hotel guests with the ability to provide the information or information they need in order to create high satisfaction. The customer relations Hotel in the Samosir area has a great ability to build relationships with hotel guests. The strategy is to create a friendly relationship with the hotel guests, giving the impression that the hotel guests need to create a good sense of satisfaction for the hotel guests. The attitude of the Customer relations Hotel in the Samosir area has always shown a friendly, easy-going attitude to the Hotel guests to create a good impression for their guests. This strategy is effective in increasing hotel guests satisfaction.

\section{REFERENCES}

[1] Kasali, Renald, Manajemen PR: Konsep dan Aplikasinya di Indonesia. Grafiti. Jakarta, 2005

[2] Wibowo, M.E, Konseling Kelompok Perkembangan. Semarang: UPTUnnes Press, 2005

[3] Cangara, Hafied, Pengantar Ilmu Komunikasi. Edisi Kedua. Jakarta : PT. Raja Geafindo Persada, 2014

[4] DeVito, Joseph A, Komunikasi Antarmanusia. Kharisma Publishing Group. Tanggerang Selatan, 2011

[5] Effendy, Onong Uchjana , Ilmu Komunikasi - Teori dan Praktek, Bandung : Remaja Rosdakarya Offset, 2006

[6] Rangkuti, Freddy, Measuring Customer Satisfaction. Jakarta : Gramedia Pustaka Utama, 2006

[7] Siagian, P. Sondang, Manajemen Komunikasi, Jakarta: Bumi Aksara, Cetakan Kesembilan, 2010

[8] Arofata, Mustafid, Penerapan Strategi Customer Relationship Management Dalam Meningkatkan Loyalitas Pelanggan Suatu Perusahaan. Yogyakarta : Jurnal Amikom, 2011

[9] Suharto Abdul Majid, Customer Service Dalam Bisnis Jasa Transportasi Jakarta : PT. Raja Grafindo Persada, 2009

[10] Kotler, Philip and Keller Kevin Lane Keller, Manajemen Pemasaran, EdisiKetigabelas. Jilid II Jakarta: PT. Gelora Aksara Pratama, 2009

[11] Umar, Organisasi dan Komunikasi. Bandung : CV. Graha Ilmu, 2005

[12] Tjiptono, Fandi, Perpektif Manajemen dan Kontemporer, Yogyakarta: Andi Offsett, 2007

[13] Ghozali, I, Structural equation modeling: Metode alternatif dengan partial least square (pls). Badan Penerbit Universitas Diponegoro, 2008

[14] Dr. K. Abdussamad and S. Thilagavathy, A Tentative Study on Consumers Perception and Image on Green Hotels - Within Trichy District, International Journal of Management (IJM), Volume 6, Issue 1, January (2015), pp. 239-244

[15] Parul Gupta1 and R.K. Srivastava, Analysis of Customer Satisfaction in Hotel Service Quality Using Analytic Hierarchy Process (AHP), International Journal of Industrial Engineering Research and Development (IJIERD), Volume 2, Issue 1, May - October (2011).

[16] Purnima Bora, Analysis of Effects of Stress on Hotel Employees. International Journal of Marketing and Human Resource Management, 8(1), 2017, pp. 01-12.

[17] Dr. Bidyut Jyoti Gogoi. Antecedents of Drivers of Satisfaction in Hotel Industry and Its Impact on Customer Loyalty. International Journal of Management, 6(8), 2015, pp. 31-41

[18] Amer Atyah Al-Khalidy, Abdul wahab N. Kadhum, and Kadhim Naief Kadhim, Application of Ground Penetrating Radar to Determine the Subsurface Features of the Project of Shams Al-Shmoos Hotel building in Al-Najaf Al-Ashraf, Iraq, International Journal of Civil Engineering and Technology, 9(6), 2018, pp. 17-27.

[19] Rosmawati Mohamad Rasit, Salasiah Hanin Hamjah and Siti Fatma Mansor, Provision of Shariah-Compliant Hotel Services towards Muslim Tourism in Malaysia, International Journal of Civil Engineering and Technology, 9(9), 2018, pp. 1815-1823. 